\title{
PENENTUAN KONDISI OPTIMUM SUHU DAN WAKTU KARBONISASI PADA PEMBUATAN ARANG DARI SEKAM PADI
}

\author{
Satriyani Siahaan, Melvha Hutapea, Rosdanelli Hasibuan \\ Departemen Teknik Kimia, Fakultas Teknik, Universitas Sumatera Utara, \\ Jl. Almamater Kampus USU Medan 20155, Indonesia \\ Email: siahaansatriyani@yahoo.com
}

\begin{abstract}
Abstrak
Arang adalah suatu bahan padat berpori yang mengandung 80 - $90 \%$ karbon yang dihasilkan dari pembakaran pada suhu tinggi (karbonisasi), sehingga bahan hanya terkarboninasi dan tidak teroksidasi menjadi karbondioksida. Penelitian ini bertujuan untuk mengetahui kondisi optimum pada proses karbonisasi dari sekam padi. Proses pengarangan dilakukan pada temperatur $400{ }^{\circ} \mathrm{C}, 500{ }^{\circ} \mathrm{C}$ dan $600{ }^{\circ} \mathrm{C}$ dengan variasi waktu 30 menit, 60 menit, 90 menit dan 120 menit. Kondisi optimum karbonisasi untuk sekam padi, yaitu pada suhu $400{ }^{\circ} \mathrm{C}$ selama 120 menit dengan kadar karbon terikat 41,3\%, kadar air 6,1\%, kadar abu 32,6\% dan kadar zat mudah menguap 20,5\%.
\end{abstract}

Kata kunci : arang, karbonisasi, sekam padi

\begin{abstract}
Charcoal is a solid porous material containing 80 - $90 \%$ of carbon being produced from combustion at high temperatures (carbonization), that the material only carbonized and not oxidized become carbon dioxide. The research is aimed to know the optimum conditions on the process of carbonization from the rice husks. The carbonization process conducted in temperatures $400^{\circ} \mathrm{C}, 500^{\circ} \mathrm{C}$ and $600^{\circ} \mathrm{C}$ with variations in time 30 minutes, 60 minutes, 90 minutes and 120 minutes. Optimum conditions carbonization for rice husk at temperature 400 ${ }^{\circ} \mathrm{C}$ for 120 minutes with a carbon content $41,3 \%$, moisture content $6,1 \%$, ash content $32,6 \%$ and volatile matter content $20,5 \%$.
\end{abstract}

Keywords : charcoal, carbonization, rice husk

\section{Pendahuluan}

Indonesia merupakan salah satu negara dengan tingkat konsumsi beras terbesar di dunia. Sebagian besar penduduk Indonesia mengkonsumsi beras sebagai makanan pokok. Konsumsi beras Indonesia sebanyak 54 juta ton pada tahun 2005, maka pengolahan padi menjadi beras akan menghasilkan jumlah limbah sekam lebih dari 10,8 juta ton [17].

Limbah sekam ini belum dimanfaatkan secara maksimal padahal merupakan bahan baku yang dapat dikembangkan dalam agroindustri, karena tersedia dalam jumlah banyak serta murah. Di samping sebagai bahan bakar, sekam padi juga dapat dimanfaatkan sebagai bahan baku pembuatan arang aktif, kertas karbon, batu baterai dan lain-lain [20] [1].

Beberapa peneliti telah melakukan penelitian tentang pembuatan arang aktif dari sekam padi, diantaranya Topallar dan Bayrak (1999) dalam Danarto dan Samun (2008) telah melakukan penelitian pembuatan adsorben dari sekam padi untuk mengadsorbsi asam stearat, palmitik, dan miristik. Hasil penelitian menunjukkan bahwa sekam padi merupakan adsorben yang cukup baik bagi ketiga senyawa tersebut [2]. Wahjuni dan Kostradiyanti (2008) meneliti mengenai pembuatan adsorben dari sekam padi dengan aktivator $\mathrm{KOH} 5 \%, 10 \%$ dan $15 \%$. Arang aktif yang dihasilkan digunakan untuk mengadsorpsi hidrogen peroksida dan hasil penelitian menunjukkan bahwa sekam padi dapat digunakan untuk menurunkan angka peroksida pada minyak kelapa tradisional sampai $84,4 \%$ [22].

Peneliti terdahulu telah banyak meneliti tentang pembuatan arang aktif dari sekam padi, namun belum ada yang menentukan kondisisi optimum dari tahap karbonisasi. Penelitian ini bertujuan untuk mendapatkan kondisi optimum dari proses karbonisasi yang menghasilkan arang dengan kadar karbon 80 - $90 \%$ [4]. Dengan diperolehnya kondisi optimum pada proses karbonisasi maka diharapkan sekam padi dapat dimanfaatkan sebagai arang sehingga dapat meningkatkan nilai ekonomis dari sekam padi.

\section{Teori}

Secara umum sekam padi berwarna kekuningan atau keemasan. Kebanyakannya mempunyai panjang 5 - 10 $\mathrm{mm}$ dan lebar 2,5 - $5 \mathrm{~mm}$. Sekam padi memiliki kerapatan jenis $1,125 \mathrm{~kg} / \mathrm{m}^{3}$. Sekam padi mempunyai komposisi kimia selulosa yang dapat dikonversi menjadi arang.

Arang adalah suatu bahan padat berpori yang dihasilkan dari pembakaran pada suhu tinggi dengan proses karbonisasi, yaitu proses pembakaran tidak sempurna, sehingga bahan hanya terkarboninasi dan tidak teroksidasi. Sebagian besar pori - pori pada arang masih tertutup dengan hidrokarbon, ter dan senyawa organik lainnya [12]. 
Arang bermanfaat sebagai sumber energi terutama jika dikembangkan menjadi briket dengan teknologi pengepresan [7]. Penggunaan briket sebagai bahan bakar sangat menguntungkan, terutama pada saat ini sedang terjadi krisis bahan bakar. Menurut Matsuzawa, dkk (2007) arang dapat dimanfaatkan sebagai sumber energi bakar [13]. Arang juga dapat dimanfaatkan sebagai pembangun kesuburan tanah [6]. Di samping itu, arang juga dapat ditingkatkan mutunya dengan cara aktivasi menjadi arang aktif.

Arang merupakan bahan yang memiliki suatu sifat fisika dan kimia tersendiri. Sifat fisika dan kimia arang dapat dilihat pada tabel 1 .

Tabel 1. Sifat Fisika dan Kimia Arang [4]

\begin{tabular}{|l|l|}
\hline Kerapatan & $0,45 \mathrm{~g} / \mathrm{cm}^{3}$ \\
\hline Kerapatan Total & $1,38-1,46 \mathrm{~g} / \mathrm{cm}$ \\
\hline Porositas & $70 \%$ \\
\hline Permukaan dalam & $50 \mathrm{~m}$ \\
\hline Kekuatan Pemampatan & $26 \mathrm{~N} / \mathrm{mm}^{2}$ \\
\hline Berat bagian terbesar & $80-220 \mathrm{~kg} / \mathrm{m}^{2}$ \\
\hline Kandungan air & $5-8 \%$ \\
\hline Kandungan karbon & $80-90 \%$ \\
\hline Kandungan abu & $1-2 \%$ \\
\hline Nilai Kalori & $29-33 \mathrm{MJ} / \mathrm{kg}$ \\
\hline Zat-zat mudah menguap & $10-18 \%$ \\
\hline
\end{tabular}

Proses pengarangan atau karbonisasi terbagi menjadi empat tahap yaitu:

1. Tahap penguapan air terjadi pada suhu $100-105^{\circ} \mathrm{C}$

2. Tahap penguraian hemiselulosa dan selulosa pada suhu $200-240{ }^{\circ} \mathrm{C}$ menjadi larutan piroglinat

3. Tahap proses depolimerasi dan pemutusan ikatan $\mathrm{C}$ O dan C - C pada suhu $240-400{ }^{\circ} \mathrm{C}$. Selain itu lignin mulai terurai menghasilkan ter.

4. Tahap pembentukan lapisan aromatik terjadi pada suhu lebih dari $400{ }^{\circ} \mathrm{C}$ dan lignin masih terus terurai sampai suhu $500{ }^{\circ} \mathrm{C}$, sedangkan pada suhu lebih dari $600{ }^{\circ} \mathrm{C}$ terjadi proses pembesaran luas permukaan arang. Selanjutnya arang dapat dimurnikan atau dijadikan arang aktif pada suhu $500-1000{ }^{\circ} \mathrm{C}$ [3].

\section{Metodologi Penelitian}

Bahan baku yang digunakan dalam penelitian ini adalah sekam padi. Peralatan yang digunakan, yaitu furnace, oven listrik, timbangan, cawan petri dan desikator. Percobaan dilakukan dengan variasi temperatur $400{ }^{\circ} \mathrm{C}, 500{ }^{\circ} \mathrm{C}$ dan $600{ }^{\circ} \mathrm{C}$ dan variasi waktu 30, 60, 90 dan 120 menit.

Bahan baku mula-mula dipisahkan dan dibersihkan dari pengotor secara manual. Kemudian ditimbang sebanyak 5 gr dan dipanaskan dalam furnace pada suhu $400{ }^{\circ} \mathrm{C}$ dengan variasi waktu 30 , 60, 90 dan 120 menit. Arang hasil karbonisasi dianalisa, yaitu analisa rendemen, kadar air, kadar abu, kadar zat mudah menguap dan kadar karbon. Prosedur yang sama dilakukan untuk variasi suhu
500 dan $600{ }^{\circ} \mathrm{C}$. Kemudian hasil analisa dibandingkan dengan sifat fisika dan kimia arang.

\section{Hasil dan Pembahasan}

Karakterisasi bertujuan untuk mengetahui sifat-sifat dasar arang hasil karbonisasi dari sekam padi. Karakterisasi tersebut meliputi analisa kadar air, abu, zat mudah menguap dan kadar karbon [10]. Tabel 2 berikut merupakan hasil penelitian yang menunjukkan karakterisasi arang dari sekam padi.

Tabel 2. Hasil Analisa Karbonisasi pada Sekam Padi

\begin{tabular}{|c|c|c|c|c|c|c|}
\hline $\begin{array}{c}\text { Suhu } \\
\left({ }^{\mathbf{}} \mathbf{C}\right)\end{array}$ & $\begin{array}{c}\text { Waktu } \\
(\mathbf{m e n i t})\end{array}$ & $\begin{array}{c}\text { Rendemen } \\
(\boldsymbol{\%})\end{array}$ & $\begin{array}{c}\text { Kadar } \\
\mathbf{A i r} \\
(\boldsymbol{\%})\end{array}$ & $\begin{array}{c}\text { Kadar } \\
\mathbf{A b u} \\
(\boldsymbol{\%})\end{array}$ & $\begin{array}{c}\text { Kadar Zat } \\
\text { Mudah } \\
\text { Menguap } \\
(\boldsymbol{\%})\end{array}$ & $\begin{array}{c}\text { Kadar } \\
\text { Karbon } \\
(\boldsymbol{\%})\end{array}$ \\
\hline \multirow{4}{*}{400} & 30 & 54,706 & 9,2 & 29,4 & 26,4 & 35 \\
\cline { 2 - 7 } & 60 & 53,274 & 8,1 & 30,3 & 25,1 & 36,5 \\
\cline { 2 - 7 } & 90 & 51,152 & 7,2 & 31,9 & 23,2 & 37,7 \\
\cline { 2 - 7 } & 120 & 48,528 & 6.1 & 32,6 & 20,5 & 41,3 \\
\hline \multirow{3}{*}{500} & 30 & 50,594 & 7,8 & 31,2 & 23,4 & 37,6 \\
\cline { 2 - 7 } & 60 & 49,572 & 6,7 & 33,1 & 21,4 & 38,8 \\
\cline { 2 - 7 } & 90 & 47,19 & 5,6 & 35,7 & 20,3 & 38,4 \\
\cline { 2 - 7 } & 120 & 45,072 & 5,2 & 38,3 & 20,9 & 35,6 \\
\hline \multirow{3}{*600}{} & 30 & 47,97 & 5,5 & 37,9 & 19,5 & 37,1 \\
\cline { 2 - 7 } & 60 & 45,79 & 5,3 & 39,9 & 19,2 & 35,6 \\
\cline { 2 - 7 } & 90 & 42,582 & 5,7 & 42,5 & 20,7 & 31,1 \\
\cline { 2 - 7 } & 120 & 38,918 & 6,2 & 46,7 & 21,04 & 26,06 \\
\hline
\end{tabular}

\section{A. Pengaruh Suhu dan Waktu Karbonisasi} Terhadap Rendemen Arang Sekam Padi

Gambar 1 menunjukkan grafik pengaruh suhu dan waktu terhadap rendemen arang dari sekam padi. Dari grafik pada suhu $400{ }^{\circ} \mathrm{C}$, rendemen yang diperoleh semakin menurun dengan bertambahnya waktu karbonisasi. Hal yang sama juga berlaku pada suhu 500 ${ }^{\circ} \mathrm{C}$ dan $600{ }^{\circ} \mathrm{C}$. Rendahnya rendemen arang ini dikarenakan reaksi antara karbon dengan uap air semakin meningkat dengan bertambahnya suhu dan lamanya waktu karbonisasi, sehingga karbon yang bereaksi menjadi $\mathrm{CO}_{2}$ dan $\mathrm{H}_{2}$ menjadi banyak, sebaliknya jumlah karbon yang dihasilkan semakin sedikit [5]. Hasil penelitian ini sesuai dengan penelitian Tirono dan Ali (2011) yang dilakukan pada tempurung kelapa, dimana semakin meningkatnya suhu dan waktu karbonisasi, rendemen arang yang dihasilkan semakin menurun [21].

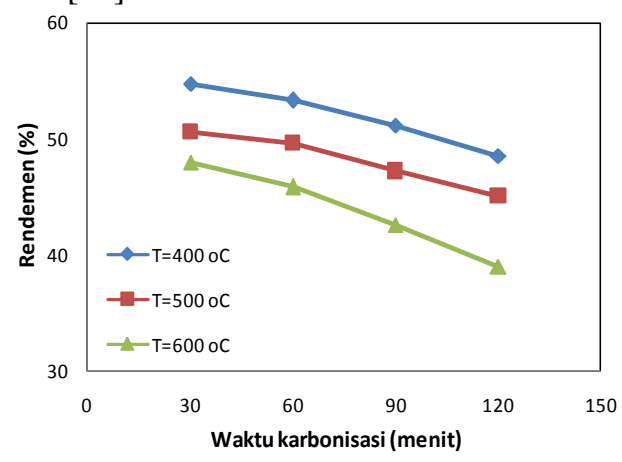

Gambar 1. Pengaruh Suhu dan Waktu Karbonisasi Terhadap Rendemen Arang Sekam Padi 


\section{B. Pengaruh Suhu dan Waktu Terhadap Kadar Air Arang Sekam Padi}

Gambar 2 menunjukkan grafik pengaruh suhu dan waktu terhadap kadar air arang sekam padi. Penetapan kadar air bertujuan untuk mengetahui sifat higroskopis arang. Menurut Hendaway (2003) kadar air dipengaruhi oleh jumlah uap air di udara, lama proses pendinginan, dan sifat higroskopis dari arang tersebut [11].

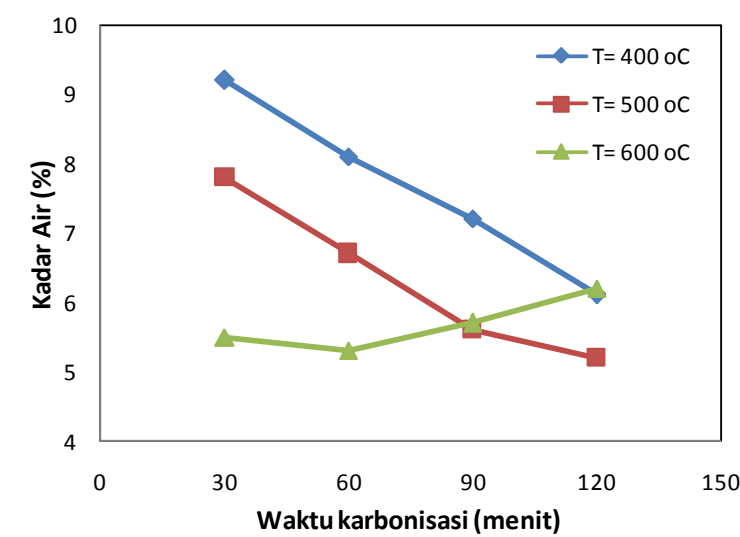

Gambar 2. Pengaruh Suhu dan Waktu Terhadap Kadar Air Arang Sekam Padi

Dari grafik pada suhu $400{ }^{\circ} \mathrm{C}$ kadar air arang sekam padi semakin menurun dengan bertambahnya waktu karbonisasi. Hal yang sama juga berlaku pada suhu 500 ${ }^{\circ} \mathrm{C}$. Namun pada suhu $600{ }^{\circ} \mathrm{C}$ waktu 90 menit grafik kadar air yang diperoleh semakin meningkat. Semakin lama proses karbonisasi seharusnya kadar air yang diperoleh semakin menurun, namun dalam hal ini yang terjadi sebaliknya. Hasil penelitian ini juga pernah diperoleh Hartanto dan Ratnawati (2010) yang dilakukan pada tempurung kelapa sawit. Hal ini disebabkan karena semakin lama waktu karbonisasi, maka pori - pori dari arang akan makin terbuka, sehingga pada saat pemindahan arang dari furnace ke desikator dan alat penimbangan, terjadi kontak langsung antara arang yang bersifat higroskopis dengan udara sehingga arang banyak menyerap uap air [8]. Walaupun kadar air yang diperoleh meningkat di beberapa titik, namun kadar air rata - rata sekam padi yang diperoleh telah sesuai dengan kadar air untuk sifat fisika dan kimia dari arang yaitu 5 $8 \%$, dimana kadar air rata-rata arang sekam padi adalah $6,55 \%$.

\section{Pengaruh Suhu dan Waktu Terhadap Kadar Abu Arang Sekam Padi}

Gambar 3 menunjukkan grafik pengaruh suhu dan waktu terhadap kadar abu arang sekam padi. Abu adalah oksida - oksida logam dalam arang yang terdiri dari mineral yang tidak dapat menguap pada proses karbonisasi. Kandungan abu sangat berpengaruh pada kualitas arang yang dihasilkan. Keberadaan abu yang berlebihan dapat menyebabkan terjadinya penyumbatan pori - pori pada arang sehingga luas permukaan arang menjadi berkurang [16].
Penentuan kadar abu bertujuan untuk menentukan kandungan oksida logam dalam arang. Semakin meningkatnya suhu dan waktu karbonisasi maka kadar abu akan semakin tinggi [19] [14].

Dari grafik pada suhu $400{ }^{\circ} \mathrm{C}$, kadar abu yang diperoleh semakin meningkat dengan bertambahnya waktu karbonisasi. Hal yang sama juga berlaku pada suhu $500{ }^{\circ} \mathrm{C}$ dan $600{ }^{\circ} \mathrm{C}$. Hasil penelitian ini sesuai dengan penelitian Purwanto (2011) yang dilakukan pada tempurung kelapa sawit, dimana semakin meningkat suhu dan waktu karbonisasi, kadar abu yang dihasilkan semakin meningkat [15]. Kadar abu rata-rata arang sekam padi adalah $35,79 \%$, hasil diperoleh tidak sesuai dengan kadar abu untuk sifat fisika dan kimia dari arang yaitu 1 - $2 \%$. Hal ini disebabkan karena tingginya suhu dan waktu karbonisasi sehingga kadar abu yang dihasilkan semakin meningkat.

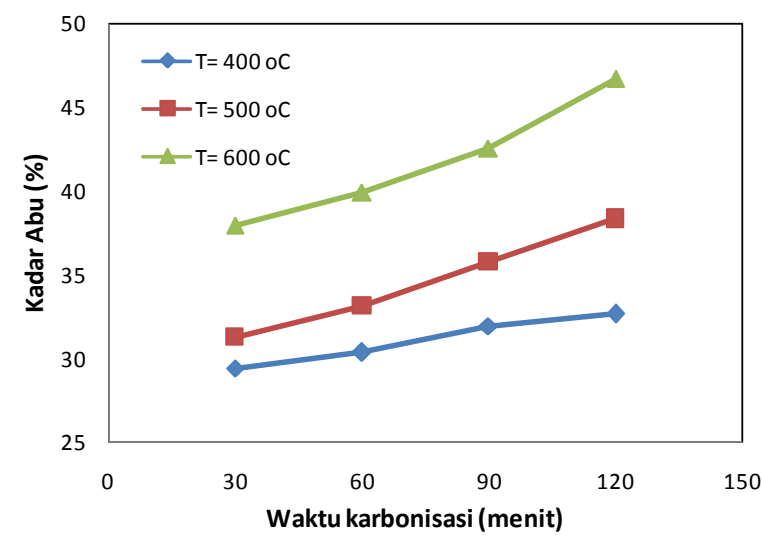

Gambar 3. Pengaruh Suhu dan Waktu Terhadap Kadar Abu Arang Sekam Padi

\section{Pengaruh Suhu dan Waktu Terhadap Kadar Zat Mudah Menguap Arang Sekam Padi}

Gambar 4 menunjukkan grafik pengaruh suhu dan waktu terhadap kadar zat mudah menguap arang sekam padi. Peningkatan suhu dan waktu akan mengurangi kadar zat mudah menguap dalam arang.

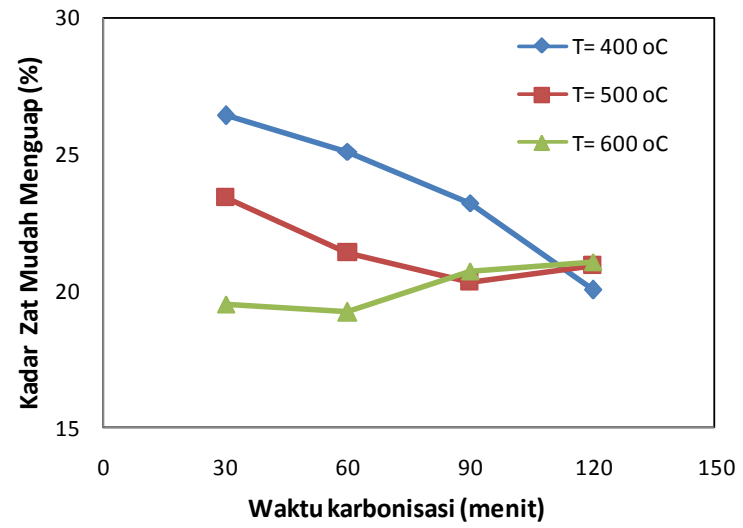

Gambar 4. Pengaruh Suhu dan Waktu Terhadap Kadar Zat Mudah Menguap Arang Sekam Padi

Tinggi rendahnya zat mudah menguap dipengaruhi oleh komponen kimia dari arang seperti adanya zat ekstraktif dari bahan baku arang. Penetapan kadar zat 
mudah menguap bertujuan mengetahui kandungan senyawa yang belum menguap pada proses karbonisasi tetapi menguap pada suhu $950{ }^{\circ} \mathrm{C}$ [18]. Pada suhu 400 ${ }^{\circ} \mathrm{C}$ (gambar 4) terlihat kadar zat mudah menguap semakin menurun dengan bertambahnya waktu karbonisasi. Hal yang sama juga berlaku pada suhu 500 ${ }^{\circ} \mathrm{C}$. Namun pada suhu $600{ }^{\circ} \mathrm{C}$ waktu 90 menit kadar zat mudah menguap yang diperoleh semakin meningkat. Hasil penelitian ini juga pernah diperoleh Wibowo, dkk (2004) yang dilakukan pada tempurung biji nyamplung [23]. Hal ini disebabkan karena adanya interaksi antara karbon dengan udara sehingga kadar zat mudah menguap yang diperoleh semakin meningkat [14]. Kadar zat mudah menguap rata-rata arang sekam padi adalah $21,76 \%$. Hasil rata - rata yang diperoleh tidak sesuai dengan kadar zat mudah menguap untuk sifat fisika dan kimia dari arang yaitu $10-18 \%$. Hal ini disebabkan karena adanya kontak antara arang dengan udara sehingga kadar zat mudah menguap yang diperoleh tinggi.

\section{E. Pengaruh Suhu dan Waktu Terhadap Kadar Karbon Arang Sekam Padi}

Gambar 5 menunjukkan grafik pengaruh suhu dan waktu terhadap kadar karbon arang sekam padi. Kadar karbon merupakan jumlah karbon murni yang terkandung di dalam arang. Suhu yang semakin tinggi pada proses karbonisasi sangat berpengaruh pada kualitas dari arang, termasuk kadar karbon. Penentuan kadar karbon bertujuan untuk mengetahui kandungan karbon setelah karbonisasi.

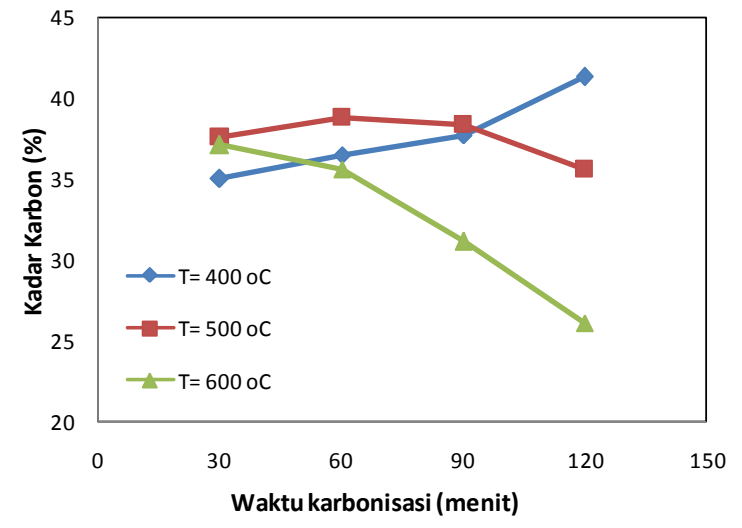

Gambar 5. Pengaruh Suhu dan Waktu Terhadap Kadar Karbon Arang Sekam Padi

Dari gambar 5 pada suhu $400{ }^{\circ} \mathrm{C}$ terlihat kadar karbon arang sekam padi yang semakin meningkat dengan bertambahnya waktu karbonisasi. Namun pada suhu $500{ }^{\circ} \mathrm{C}$ dan $600{ }^{\circ} \mathrm{C}$ kadar karbon yang diperoleh semakin menurun. Hal ini disebabkan karena tingginya suhu dan waktu dalam karbonisasi sehingga terjadi kerusakan pelat - pelat karbon, karena terjadi oksidasi yang berlebihan. Meningkatnya daya oksidasi, baik oleh suhu yang tinggi maupun oleh gas pengoksidasi akan menyebabkan kerusakan dinding pori, sehingga luas permukaan dinding pori akan menurun dan kadar karbon yang diperoleh lebih kecil [9]. Kadar karbon tertinggi yang diperoleh adalah $41,3 \%$ pada suhu $400{ }^{\circ} \mathrm{C}$ dengan waktu karbonisasi 120 menit. Titik ini menunjukkan kondisi optimum karbonisasi pada sekam padi. Kadar karbon rata - rata arang sekam padi adalah 35,89\%. Namun hasil yang diperoleh masih jauh dari standar fisika dan kimia arang untuk kadar karbon, yaitu 80 $90 \%$.

\section{Kesimpulan}

1. Semakin lama waktu dan semakin tinggi suhu karbonisasi maka rendemen yang dihasilkan semakin sedikit.

2. Semakin lama proses karbonisasi maka semakin kecil kadar airnya.

3. Semakin meningkatnya suhu dan waktu karbonisasi maka kadar abu akan semakin tinggi.

4. Peningkatan suhu dan waktu karbonisasi akan mengurangi kadar zat mudah menguap.

5. Suhu dan waktu karbonisasi optimum untuk sekam padi, yaitu $400{ }^{\circ} \mathrm{C}$ selama 120 menit dengan kadar karbon terikat 41,3\%, kadar air 6,1 \%, kadar abu $32,6 \%$ dan kadar zat mudah menguap $20,5 \%$.

\section{Daftar Pustaka}

[1] Balai Informasi Pertanian Departemen Pertanian, Arang Tempurung. Departemen Pertanian, Propinsi Sulawesi Utara, Menado, 1987.

[2] Danarto. YC dan Samun. T, Pengaruh Aktivasi Karbon Dari Sekam Padi Pada Proses Adsorpsi Logam Cr(VI). EKUILIBRIUM., $\quad$ Vol. 7, No. 1. Januari 2008: 13 - 16. Jurusan Teknik Kimia. Fakultas Teknik. UNS. Surakarta, 2008.

[3] Djatmiko, B., S. Ketaren dan S. Setyahartini, Pengolahan Arang dan Kegunaannya. Agro Industri Press, Jurusan Teknologi Industri Pertanian, Fakultas Teknologi Pertanian IPB, Bogor, 1985.

[4] Ensiklopedia Nasional Indonesia, Sifat Fisika dan Kimia Arang, Jil.2. Departemen pandidikan Nasional, Jakarta, 1995.

[5] Ferry, Arang Aktif. Karya Tulis Institut Pertanian Bogor. IPB Repository Home. http://repository.ipb.ac.id, Bogor, 2002.

[6] Gusmailina dan Pari, G., Pengaruh Pemberian Arang Terhadap Pertumbuhan Tanaman Cabai Merah (Capsicum annum), Buletin Penelitian Hasil Hutan. 20(3). 217-229, Bogor, 2002.

[7] Haji, A.G., Konversi Sampah Organik Menjadi Komarasca (Kompos-Arang Aktif- Asap Cair) dan Aplikasinya Pada Tanaman Daun Dewa, Disertasi. Sekolah Pascasarjana, IPB Bogor, 2007.

[8] Hartanto, Singgih dan Ratnawati, Pembuatan Karbon aktif dari Tempurung Kelapa Sawit dengan Metode Aktivasi Kimia, Jurnal Sains Materi Indonesia Vol. 12, No. 1, 
hal : 12 - 16. ISSN : 1411-1098. Program Studi Teknik Kimia, FTI-ITI. Tangerang, 2010.

[9] Hartoyo dan Nurhayati, Pengaruh Berat Jenis Kayu Daun Lebar terhadap Sifat Arang. Laporan No.72, LPHH, Bogor, 1976.

[10] Hajil. A Gani. Gustan Pari, Habibati, Amiruddin dan Maulina, Kajian Mutu Arang Hasil Pirolisis Cangkang Kelapa Sawit, Jurnal Purifikasi, Vol. 11, No. 1, Juli 2010.

[11] Hendaway, ANA, Influence of $\mathrm{HNO}_{3}$ oxidation on the structure and adsorptive properties of corncob-based activated carbon, Carbon 41:713-722. Elsevier. UK, 2003.

[12] Kinoshita, K, Carbon Electrochemical and Physicochemical Properties, John Wiley \& Sons, New York, 1988

[13] Matsuzawa, Y., Mae, K., Hasegawa, I., Suzuki, K., Fujiyoshi, H., Ito, $\mathbf{M}$ dan Ayabe, M. Characterization of Carbonized Municipal Waste as Substitute for Coal Fuel, $86 . \quad 264-$ 272, Japan, 2007.

[14] Pari, G, Kajian struktur arang aktif dari serbuk gergaji kayu sebagai adsorben formaldehida kayu lapis, Disertasi. Program Pascasarjana, Institut Pertanian Bogor. Bogor, 2004.

[15] Purwanto Djoko, Arang Dari Limbah Tempurung Kelapa Sawit, Jurnal Penelitian Hasil Hutan Vol. 29 No. 1, Maret 2011: 57- 66, Bogor, 2011.

[16] Scroder Eliabeth, "Experiment on the Generation of activated carbon from Biomass", Institute for Nuclear and energy Technologies Forschungs Karlsruhe, hal 106-111, Germany, 2006.

[17] Sihotang A, Abduh Ahsan dan Dian putrid Sabila, Pemanfaatan Limbah Sekam Padi Menjadi Arang Aktif Sebagai Adsorben. http://repository.ipb.ac.d/handle/123456789/32 424, Bandung, 2009.

[18] Sudradjat R., Anggorowati dan D. Setiawan, Pembuatan Arang Aktif dari Kayu Jarak Pagar, Jurnal Penelitian Hasil Hutan, Pusat Litbang Hasil Hutan, Bogor, 2005.

[19] Sudradjat, R. dan S. Ani, Pembuatan dan pemanfaatan arang aktif dari ampas daun teh, Buletin Penelitian Hasil Hutan. 20 (1): 1 - 11. P3HH. Bogor, 2002.

[20] Thorbun, C., Rice Husks as Fuel, PT Tekton Books, Development Tehnology CenterBandung Institute of Tehnology (DTC ITB), Bandung, 1982.

[21] Tirono. M dan Ali Sabit, Efek Suhu Pada Proses Pengarangan Terhadap Nilai Kalor Arang Temapurung Kelapa, Jurnal Neutrino Vol. 3, No. 2. Fakultas Sains dan Teknologi UIN Maulana Malik Ibrahim, Malang, 2011.

[22] Wahjuni. S dan Betty Kostradiyanti, Penurunan Peroksida Minyak Kelapa Tradisional dengan
Adsorben Arang Sekam Padi IR 64 Yang Diaktifkan Dengan Kalium Hidroksida, Jurnal Kimia 2. Jurusan Kimia FMIPA Universitas Udayana, Bukit Jimbaran, 2008.

[23] Wibowo. Santiyo, Wasrin Syafii dan Gustan Pari, Karakteristik Arang Aktif Tempurung Biji nyamplung (Calophyllum inophyllum Linn).Fakultas Kehutanan, IPB, Kampus IPB Darmaga, Bogor, 2004. 